\title{
COVID-19: Reflections, So Far
}

\author{
Partha S Ray
}

\section{Abstract}

Never in the history of mankind has the global scientific and medical community been subjected to such a testing time as in the coronavirus-2019 (COVID-19) pandemic triggered off by the novel RNA severe acute respiratory syndrome-coronavirus 2 (SARS-CoV-2) virus of $125 \mathrm{~nm}$ size. Despite the concerted efforts of the entire world, we do not seem to be making progress in being able to confidently recommend evidence-based pharmacological interventions in affected patients or advise governments on immunological interventions to avoid mass fatalities that are already in very significant numbers throughout the developed and the developing world including unfortunately in India. This has been a wake-up call for researchers, virologists, and immunologists to undertake more critical research into the deficiencies of our knowledge base that has been exposed by the current pandemic. The shift of recent research since the last HIV scare in the early 1980s has been toward noncommunicable diseases and drug development has also followed the same trend. There has been considerable progress on antibiotic resistance although antiviral therapies have not made progress in line with potential emergence of novel viruses as has been cruelly demonstrated in this current pandemic. The immunological responses that have been so varied to the current pathogen in individuals are again a matter of further research and understanding of human immunology and its complex response to cancers, autoimmune diseases, and external pathogens-further research is necessary here. The long-term impact of COVID-19 illness spectrum remains to be seen as clinicians and basic scientists put their heads together to evaluate the clinical profile of the illness spectrum from case records of recovered patients and those who succumbed and evidence-based treatment approaches need to be available instead of the best guess treatments that we are practicing presently to save lives. Immunologists, virologists, clinical trial experts, and pharmacologists are now tasked to develop evidence-based pharmacological therapies and efficient vaccines to rebuild the confidence of the population and governments globally who have always relied upon and respected healthcare stakeholders to protect global health. We live in uncertain times filled with anxiety and disruption of normal human lifestyle habits. Never has the tolerance, patience, and fortitude of the global village, we live in and of the economic fallouts arising been tested to the hilt as much as we have seen in these last six months. Hopefully, we should be able to see the light at the end of the "COVID-19" tunnel soon. Going forward, we hope we emerge as a stronger human civilization being able to collaborate, cooperate, and cohabit this beautiful planet and together we become masters of our destiny so that future generations will be grateful to us for having taken responsible decisions during times of crisis that threatened our civilization and brought all of us proverbially to our knees.

Keywords: Atlanta, Centers for Disease Control and Prevention, COVID-19, Global economy, Lockdown, Middle East respiratory syndrome, Quarantine, Severe acute respiratory syndrome coronavirus type 2, Suicide, Swachh Bharat, World Health Organization.

Bengal Physician Journal (2020): 10.5005/jp-journals-10070-7019

Coronavirus-2019 (COVID-19) ${ }^{1}$ and the severe acute respiratory syndrome-coronavirus 2 (SARS-CoV-2) ${ }^{2}$ have humbled both science and medicine. Ever since the development of antibiotics between the two world wars ${ }^{3}$ that effectively treated the bacterial infections and furthermore research and development into antiviral therapies including those for $\mathrm{HIV}_{1}^{4}$ we managed to effectively treat most known infections leading to a premature satisfaction and potential complacence and subtle arrogance and lack of effort into research and development looking into unknown threats in the future to suddenly surprise us.

Lately, the focus has been on drug-resistant organisms ${ }^{5}$ and fungal species ${ }^{6}$ and reasonable progress has been made in regard to therapeutics in these difficult areas as well. The occasional emergence of virulent viral infections and other microbes like Ebola ${ }^{7}$ has remained geographically essentially restricted to the so-called less privileged countries leading to inadequate focus on research into those viruses and organisms. The "big" pharmaceutical industry ${ }^{8}$ was also not quite interested unless patients with Ebola were, through travel, spreading the disease into the Western world. The more recent SARS-CoV-1 and MERS ${ }^{9}$ infections that have a genetic similarity to the present COVID-19 causative RNA virus have also possibly not been studied potentially exhaustively as they remained localized and never assumed pandemic proportions. In retrospect, the countries affected by these two preceding viruses,
Department of Neurology, NHS England, The Walton Centre for Neurology, Liverpool, England.

Corresponding Author: Partha S Ray, Department of Neurology, NHS England, The Walton Centre for Neurology, Liverpool, England, Phone: +44 7759491315, e-mail: partha_ray@hotmail.com

How to cite this article: Ray PS. COVID-19: Reflections, So Far. Bengal Physician Journal 2020;7(2):39-42.

Source of support: Nil

Conflict of interest: None

if they had done further research including the rich Middle Eastern countries who unfortunately had MERS, with a very high case fatality rate; we perhaps might have had better preparedness in regard to the current pandemic.

In addition, the clinical symptoms and signs produced by this virus seem to surprise experts on a perpetual basis till date. ${ }^{10}$ This is the perception from studying the information disseminating from university medical centers globally. The debate seems to center around what is causative to the virus and what is coincidental from comorbidities and immunological variations in response from the population. Unfortunately, this seems to be the knowledge base despite the disease raging for the last seven months in the entire world including with a fair number of autopsy studies ${ }^{11,12}$ and yet 
expert opinion seems to be really cautious and guarded and at best ambivalent.

Such lack of confidence from the scientific community and virologists is bound to scare and result in generalized anxiety among the population who have relied on medical experts to be able to give them constructive and confirmed opinions in the past. The population have relied on us to guide them scientifically in distressed times. This ambivalence has affected public health measures as well, as seven months into the disease we have often seen globally double standards in social distancing guidelines/ requirements ${ }^{13}$ as well as in hand hygiene and the wearing of masks including the types of masks. There have been occasional wrangles in the rules of the provision and donning of personal protective equipment ${ }^{14}$ to frontline medical, nursing, and ancillary staff. They are delivering superlative care globally under extreme circumstances. These "COVID warriors" are putting their lives at risk and that of their families on a day-to-day basis by coming potentially into the first-degree contact with a deadly virus on a daily basis.

Again, the prevalence of asymptomatic infection ${ }^{15}$ in communities and medical facilities perpetuating ongoing spread of the virus through unrecognized individuals continues to be another discussion point among public health experts. Everyone globally has tried their level best to come up with the best possible solutions in this everchanging scenario to protect the best interests of their respective populations. Our research into novel viruses has not kept pace with the mutations that the viruses have made to challenge humans as in this case. With hindsight, we should have done more and seen this coming!

Unfortunately, the USA has suffered most casualties till date ${ }^{16}$ despite having an apparently solid health infrastructure that has been exposed by this virus while lesser organized countries have somehow managed in desperate anxiety when the pandemic was at its peak from the situation so far. It is unfortunate that as of January 19, 2021, India comes third in this list behind USA and Brazil followed by Mexico and the UK and Italy next. That the virus has not respected economies or healthcare setups are borne out by the ominous league table of deaths worldwide.

There seems to be an unexplained difference in the immunological response ${ }^{17}$ to the virus among populations and individuals, and we had hoped some substantiate data to explain the same should have emerged by now to assist treatment planning and prognostication and resource allocation for medical care in populations. This has certainly not helped governments to formulate national strategies to advise and rescue populations from the scourge of the virus. The vulnerable, infirm, and deprived people all over the world thus suffer most or are forced to remain isolated in fear of death.

We have learnt lessons to prepare for future threats like this one that has turned out to be an existential threat for humanity by establishing stronger global collaboration between nations. The World Health Organization ${ }^{18}$ and specialized agencies in this field with an experience like the CDC, Atlanta, ${ }^{19}$ would guide and lead initiatives for countries to develop their own infrastructure of research and development against pathogens as they would be the primary stakeholders in the protection and health of their respective populations to avoid a recurrence and a pandemic illness. This 125-nm RNA virus has caused havoc among all sections of the global population and has caused widespread casualties. ${ }^{20,21}$

It is unfortunate that in late December 2019 and early 2020, biological warfare ${ }^{22}$ as part of sensational journalism including medical journals seemed to be the flavor that COVID-19 was being touted as instead of timely precautions being taken. At this time, cooperation between nations coming in the way of the viral spread and restriction of peoples' movements and air travel to avoid rapid and long-distance transmission of the virus to wider parts of the globe with a highly infective viral particle would have saved thousands of lives. This was potentially achievable if wholehearted efforts had been made in that direction. With hindsight, we should have had measures in place akin to the layers of safety surrounding the apocalyptic nuclear button.

The media exposure has predominantly been overbalanced to those parts in the developed countries that have suffered while the areas in under-resourced areas have not been proportionately voiced. We live in a global health environ for communicable diseases for which we need robust organizations like WHO and responsible international media partners who can advocate and bring to the forefront the needs of every individual on our globe uniformly. ${ }^{23,24}$

Health education, health promotion, and healthcare dissemination have suffered globally more in some areas than others as the focus has shifted from communicable to noncommunicable diseases, and big global pharmaceutical companies have shifted their R\&D focus to noncommunicable diseases as the profitability of drug development is higher for those disorders. ${ }^{25}$ With a large number of molecules that can be accessed from their historic pharmacological development libraries to produce new chemicals with new patents as part of the business model, they have shifted to the modern epidemics of diabetes, hypertension, cardiac illness, and cancers to have shareholder accountability. ${ }^{26}$ The funding of research into basic science, basic immunology, and biomolecular developments needs to be more government-funded particularly in resource-limited countries like India so that we are able to utilize the great human intellectual potential of our young scientists and bioengineers to develop the health of our own nation and to share our expertise with consenting partnering countries in the global interest. $^{27}$

This pandemic has also exposed the global health infrastructure in regard to its inability to handle large numbers of sick people requiring intensive care at any one time. ${ }^{28}$ This has been seen in both resource-constrained and resource "supposedly" surplus healthcare systems. ${ }^{29}$ The basic expenditure on health and social care in terms of GDP is very restricted globally and worse in underresourced systems than in better off systems. ${ }^{30}$ This has led to generalized anxiety among all and overall directionless ad hoc official orders or circulars to protect the population at large as a knee-jerk response. However, the opposing forces of economy and livelihood and the populist interests have had to be balanced against restricting normal human behavior by "quarantine" and "lockdown" measures. ${ }^{31}$

Mental health of population has not been addressed as the restriction of livelihood, recreation, and human habits of socialization and congregation has been over many months now internationally. ${ }^{32}$ There is the accompanying fear and anxiety for the future (global economy, jobs, health, relations, education, etc.) that has been expressed in a number of ways including suicide, domestic violence, mob mentality, and severe depression. These have largely been overlooked globally. ${ }^{33}$ This has affected both young and old as in our lifetimes over the last century, such a prolonged alteration of human behavior has never been witnessed (apart from the world wars and that too in the war zones only in those times). It has been difficult to sustain hope as a doctor (as that is the last entity we cannot take away from people) that eventually either the horror of this virus will be a thing of the past, as the natural coexistence of this 
novel coronavirus and the human population will be established through immunological alterations or genetic alterations within the virus and human genetics occur enabling a "semi peaceful coexistence" in the least. $^{34}$

We are informed that this virus will be around for quite some time hopefully with diminishing virulence and infectivity as per epidemiology of novel viruses that cohabit with the human race, and hence, the advised public infection control measures will lead to the vast change in the way we interact with others, travel, do business, and conduct ourselves generally. ${ }^{35}$ This will be a major lifestyle change for everyone on this planet. With population concentrations in metropolises and in urban areas including underprivileged sections of society globally that we are aware of, the virus might again take off once the infectivity crosses the critical threshold any time in the future. Epidemiologists and public health experts would have to look into this further, as would statisticians and mathematical modeling experts who have to provide better solutions and data for the future, for government agencies. ${ }^{36}$

We all heard of extensive antibody testing/contact tracing and the rolling out of vaccines as the ultimate solution. This is already in progress including in India, UK and USA successfully and we await to see the benefits of vaccination in due course; the track and trace is no longer a priority presently after being a focus in the initial months for herd immunity assessments then. It would be nice to know if these were full-proof solutions and the affordability of such measures to ensure that these would be effective should the virus comeback as a second or third waves to threaten us and persist for years into the future. ${ }^{37}$ Business models of vaccine development that many countries have pursued at breakneck speed will impact on the development and distribution of the same to build up global immunity as a natural deterrent to this virus. Providing financial health and vaccine aid to the worst-hit countries would be necessary as it would be in the global interest to do. A collaborative relationship between the industrialized nations who are relatively well resourced and the global health monitor World Health Organization (WHO) need to be firmed, for now is the time for historic unification to protect humanity. This virus knows no geographical boundaries as it spreads through the air that we all share and take for granted and that is where we fall if we go our different ways and if we do not collaborate and cooperate globally sincerely and without prejudice. ${ }^{38}$

The COVID-19 has been an eye-opener for all of humanity. Now is the time to learn from our mistakes of humans taking our civilization for granted and to believe that we can survive without respecting the needs, interests, and wants of our neighbors. The callous, greedy, selfish lifestyles that we have all adopted to without reverence to the global climate, other animals and birds and plants (that can spread diseases in the future), the global warming, and water resources have now been rudely shaken up so that we wake up and begin to change our attitudes, practices, and lifestyles. ${ }^{39}$

A large number of lives have been lost and millions more have suffered silently in these COVID-19 times. We are still not sure whether the end is in sight and when, although we all pray that we can see the light at the end of the COVID-19 tunnel-[Sanskrit] (तमसो मा ज्योतिर्गमय)—असतो मा साद गमय, तमसो मा ज्योतिर् गमय, मृत्योर मा अमृतम् गमय (Asato Ma Sad Gamaya, Tamaso Ma Jyotir Gamaya, Mrityor Ma Amritam Gamaya)—Bṛhadāraṇyaka Upanișad. ${ }^{40}$

I hope we all have had the eye-opener to live in peaceful coexistence with one another and have the ultimate realization that all of us are equally vulnerable and no one is safe unless we adopt clean habits as personal measures (स्वच्छ भारत अभियान Swacch Bharat) as our scientists do more research to understand novel pathogens that biologists warn will flourish as the world warms up, seas rise, and polar caps melt. Our children and grandchildren will not thank us if we did not do our duties to protect our planet and human civilization sincerely.

\section{References}

1. Coronavirus. Wikipedia, the free encyclopaedia. Retrieved on July 26, 2020. Available from: https://en.wikipedia.org/w/index. php?title $=$ Coronavirus\&oldid $=969499748$

2. Coronavirus disease 2019. Wikipedia, the free encyclopaedia. Retrieved on July 26, 2020. Available from: https://en.wikipedia.org/w/ index.php?title=Coronavirus_disease_2019\&oldid=969612857

3. Adedeji WA. The treasure called antibiotics. Ann lb Postgrad Med 2016;14(2):56-57. PMID: 28337088, PMCID: PMC5354621.

4. Arts EJ, Hazuda DJ. HIV-1 antiretroviral drug therapy. Cold Spring Harb Perspect Med 2012;2(4):a007161. DOI: 10.1101/cshperspect.a007161.

5. Prestinaci F, Pezzotti P, Pantosti A. Antimicrobial resistance: a global multifaceted phenomenon. Pathog Glob Health. 2015;109(7):309318. DOI: 10.1179/2047773215Y.0000000030.

6. Cowen LE. The evolution of fungal drug resistance: modulating the trajectory from genotype to phenotype. Nat Rev Microbiol 2008;6(3):187-198. DOI: 10.1038/nrmicro1835.

7. Chowell G, Nishiura H. Transmission dynamics and control of Ebola virus disease (EVD): a review. BMC Med 2014;12:196. DOI: 10.1186/ s12916-014-0196-0.

8. List of largest biomedical companies by revenue. Wikipedia, the free encyclopaedia. Retrieved on July 26, 2020. Available from: https:// en.wikipedia.org/w/index.php?title=List_of_largest_biomedical_ companies_by_revenue\&oldid $=966143403$

9. Ramadan N, Shaib H. Middle East respiratory syndrome coronavirus (MERS-CoV): a review. Germs. 2019;9(1):35-42. DOI: 10.18683/ germs.2019.1155.

10. Chen N, Zhou M, Dong X, et al. Epidemiological and clinical characteristics of 99 cases of 2019 novel coronavirus pneumonia in Wuhan, China: a descriptive study. Lancet 2020;395(10223):507-513. DOI: 10.1016/S0140-6736(20)30211-7.

11. Yi ES, Cecchini MJ, Bois MC. Pathologists in pursuit of the COVID-19 culprit. Lancet Infect Dis 2020;20(10):1102-1103. DOI: 10.1016/ S14733099(20)30449-7.

12. Carsana L, Sonzogni A, Nasr A, et al. Pulmonary post-mortem findings in a series of COVID-19 cases from northern Italy: a twocentre descriptive study. 2020;20(10):1135-1140. DOI: 10.1016/S14733099(20)30434-5.

13. Chu DK, Akl EA, Duda S, et al. Physical distancing, face masks, and eye protection to prevent person-to-person transmission of SARSCoV-2 and COVID-19: a systematic review and meta-analysis. Lancet 2020;395(10242):1973-1987. DOI: 10.1016/S0140-6736(20)31142-9.

14. Herron JBT, Hay-David AGC, Gilliam AD, et al. Personal protective equipment and COVID 19 a risk to healthcare staff? Br J Oral Maxillofac Surg 2020;58(5):500-502. DOI: 10.1016/j.bjoms.2020.04.015.

15. Gandhi M, Yokoe DS, Havlir DV. Asymptomatic transmission, the Achilles' heel of current strategies to control Covid-19. N Engl J Med 2020;382(22):2158-2160. DOI: 10.1056/NEJMe2009758.

16. Omer SB, Malani P, del Rio C. The COVID-19 pandemic in the US: a clinical update. JAMA 2020;323(18):1767-1768. DOI: 10.1001/jama.2020.5788.

17. Vabret N, Britton GJ, Gruber C, et al. Immunology of COVID-19: current state of the science. Immunity 2020;52(6):910-941. DOI: 10.1016/j. immuni.2020.05.002.

18. Sohrabi C, Alsafi Z, O'Neill N, et al. World Health Organization declares global emergency: a review of the 2019 novel coronavirus (COVID19) [published correction appears in Int J Surg 2020 May; 77:217]. Int J Surg 2020;76:71-76. DOI: 10.1016/j.ijsu.2020.02.034.

19. Ghinail, McPherson TD, Hunter JC, et al. First known person-to-person transmission of severe acute respiratory syndrome coronavirus 2 (SARS-CoV-2) in the USA. Lancet 2020;395(10230):1137-1144. DOI: 10.1016/S0140-6736(20)30607-3. 
20. Tomar A, Gupta N. Prediction for the spread of COVID-19 in India and effectiveness of preventive measures. Sci Total Environ 2020;728:138762. DOI: 10.1016/j.scitotenv.2020.138762.

21. Kumar SU, Kumar DT, Christopher BP, et al. The rise and impact of COVID-19 in India. Front Med 2020;7:250. DOI: 10.3389/ fmed.2020.00250.

22. Lippi G, Sanchis-Gomar F, Henry BM. COVID-19: unravelling the clinical progression of nature's virtually perfect biological weapon. Ann Transl Med 2020;8(11):693. DOI: 10.21037/atm-20-3989.

23. UN News. "This is a time for facts, not fear," says WHO chief as COVID19 virus spreads. Retrieved on February 15, 2020 Health. Available from: https://news.un.org/en/story/2020/02/1057481

24. Julian Borger in Washington (Apr 8, 202023.53 BST). Trump scapegoating of WHO obscures its key role in tackling pandemic. Available from: https://www.theguardian.com/world/2020/apr/08/ world-health-organization-coronavirus-donald-trump

25. Patnaik S, Pereira V, Temouri Y. Getting our act together for COVID-19 drug development. Issues in Science and Technology. Retrieved on May 21, 2020. Available from: https://issues.org/ covid-19-drug-development-infectious-disease-partnerships/ \#.Xx3QNp8pgEc.link.

26. Amin T, Malpani R. Covid-19 has exposed the limits of the pharmaceutical market model. Retrieved on May 19, 2020. Available from: https://www.statnews.com/2020/05/19/covid-19-exposedlimits-drug-development-model/

27. WHO: 2019 novel Coronavirus global research and innovation forum: towards a research roadmap. Available from: https://www.who.int/ blueprint/priority-diseases/key-action/Roadmap-version-FINAL-forWEB.pdf?ua $=1$

28. Gaffney A, Himmelstein DU, Woolhandler S. COVID-19 and US health financing: perils and possibilities. Int J Health Serv 2020;50(4):396407. DOI: $10.1177 / 0020731420931431$.

29. Nicola M, Alsafi Z, Sohrabi C, et al. The socio-economic implications of the coronavirus pandemic (COVID-19): a review. Int J Surg 2020;78:185-193. DOI: 10.1016/j.jju.2020.04.018.

30. McKee M, Stuckler D. If the world fails to protect the economy, COVID19 will damage health not just now but also in the future. Nat Med 2020;26:640-642. DOI: 10.1038/s41591-020-0863-y.
31. Kakar A, Nundy S. COVID-19 in India. J R Soc Med 2020;113(6):232-233. DOI: 10.1177/0141076820927668.

32. Varshney M, Parel JT, Raizada N, et al. Initial psychological impact of COVID-19 and its correlates in Indian Community: an online (FEEL-COVID) survey. PLoS One 2020;15(5):e0233874. DOI: 10.1371/ journal.pone.0233874.

33. Krishnakumar B, Rana S. COVID 19 in INDIA: strategies to combat from combination threat of life and livelihood. J Microbiol Immunol Inf 2020;53(3):389-391. DOI: 10.1016/j.jmii.2020.03.024.

34. Bandyopadhyay S. Coronavirus disease 2019 (COVID-19): we shall overcome. Clean Technol Environ Policy 2020;22:545-546. DOI: 10.1007/s10098-020-01843-w.

35. Li H, Liu SM, Yu XH, et al. Coronavirus disease 2019 (COVID-19): current status and future perspectives. Int J Antimicrob Agents 2020;55(5):105951. DOI: 10.1016/j.ijantimicag.2020.105951.

36. Kucharski AJ, Russell TW, Diamond C, et al. Early dynamics of transmission and control of COVID-19: a mathematical modelling study. Lancet Inf Dis 2020;20(5):553-558. DOI: 10.1016/S1473-3099(20)30144-4.

37. Patel R, Babady E, Theel ES, et al. Report from the American Society for Microbiology COVID-19 International Summit, 23 March 2020: value of diagnostic testing for SARS-CoV-2/COVID-19. mBio 2020;11(2):e0072220. DOI: $10.1128 / \mathrm{mBio} .00722-20$.

38. Peeling RW, Wedderburn CJ, Garcia PJ, et al. Serology testing in the COVID-19 pandemic response. Lancet 2020;20:E245-E249. DOI: 10.1016/S1473-3099(20)30517-X.

39. Khawaja MA.COVID-19 pandemicand the global humanity.05.04.2020Pressenza New York. Available from: https://www.pressenza.com/ 2020/04/covid-19-pandemic-and-the-global-humanity/

40. pavamāna abhyāroha (abhyāroha, lit. "ascending," being a Upanishadic technical term for "prayer." Pavamana Mantras the Bṛhadāranyaka Upanișad "From falsehood lead me to truth, from darkness lead me to the light, from death lead me to immortality." These three statements are referred to as the three Pavamana Mantras. Some renderings add ॐँ (om) at the beginning and ॐँ शानतः शान्तः शानत्तः ॥ (om śāntịn śāntiḥ śāntiḥ, "om peace peace peace") as a fourth line. This is a stylistic addition that concludes a recitation; as such, it is often included with the verse itself though the Upanishad itself does not end the line that way. 